\title{
Coastal Aquaculture Development in Eastern Africa and the Western Indian Ocean: Prospects and Problems for Food Security and Local Economies
}

This paper reviews the experience and status of coastal aquaculture of seaweeds, mollusks, fish and crustaceans in eastern Africa and the islands of the western Indian Ocean. In many respects, coastal aquaculture is still in its infancy in the region, and there is a pressing need to formulate development strategies aimed at improving the income and assuring the availability of affordable protein to coastal communities. This paper also draws from positive and negative experiences in other parts of the world. The requirements of feed and fry, and the conversion of mangroves are used to illustrate how some aquaculture activities constitute a net loss to global seafood production. The paper presents both general and specific sustainability guidelines based on the acknowledgement of aquaculture as an ecological process. It is concluded that without clear recognition of its dependence on natural ecosystems, the aquaculture industry is unlikely to develop to its full potential in the region.

\section{INTRODUCTION}

Coastal aquaculture production have been increasing rapidly in the past decade, whereas capture fisheries is facing serious problems of overfishing of depleted stocks, especially in marine waters $(1,2)$. Most coastal aquaculture development has taken place in Asia, Europe, and South America, whereas relatively modest production has been achieved in Africa.

Today, aquaculture supplies more than one fourth of all fish (both freshwater and marine species) that humans eat (2). The average fish consumption per person in the world was $16.1 \mathrm{~kg}$ yr-I in 2000. Different regions, however, show very dissimilar trends. Whereas fish supply in Asia increased by about $70 \%$ between 1984 and 2000 reaching $17.7 \mathrm{~kg}$ person $^{-1} \mathrm{yr}^{-1}$, it decreased by $14 \%$ in Africa from 7.9 to $6.8 \mathrm{~kg}$ person-I $\mathrm{yr}^{-1}$ during the same period. Even to maintain the comparatively low 2000 per capita supply levels in 2010, the continent would need an additional 1.8 million tonnes $(\mathrm{t})$ of fish annually, based on estimates that the' population will grow from 757 to 993 million people over the same period (3). Taking into account the population trends in Africa, the state of commercial fish stocks and the poor prospects for increasing the supply from capture fisheries, it would be a major challenge to raise aquaculture production this much (3). Such increased aquaculture production would mainly be based upon inland freshwater aquaculture, but coastal aquaculture could also supplement the diets of coastal villagers with fish protein in addition to providing new sources of income.

The potential of coastal aquaculture to improve the income and assure the availability of affordable protein to the poor in developing countries has been impeded by the emphasis on the industrial-scale cultivation of high-valued carnivorous species destined for export markets in Europe, USA and Japan. The primary motives are generating high profits for investors and input suppliers and enhancing export earnings for national treasuries. This is particularly true for intensive shrimp farming, which have been severely criticized for the environmental and

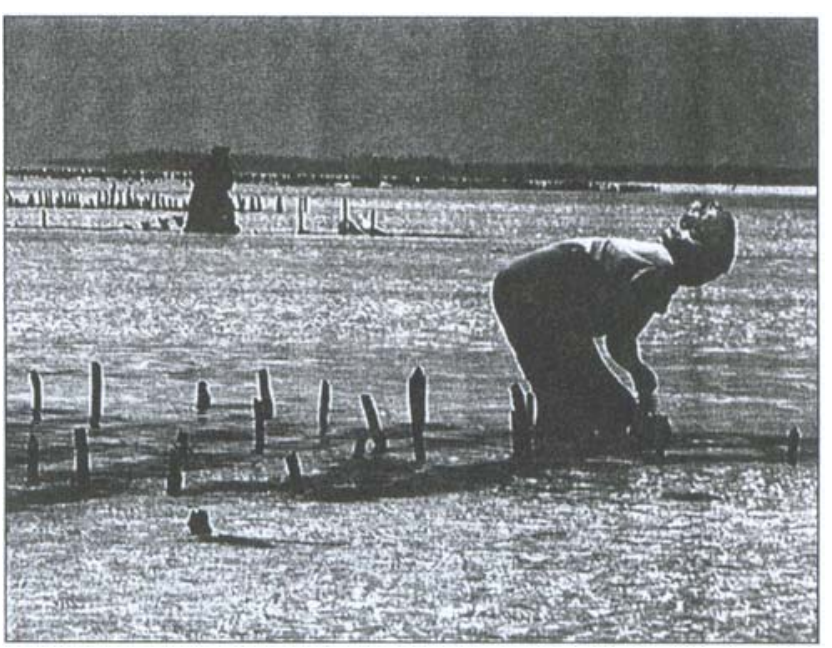

Seaweed farms in Zanzibar, Tanzania. Photo: I. Bryceson.

socioeconomic problems generated in its backwaters (4-6).

This paper presents an overview of the experience and status of coastal aquaculture in eastern Africa and the islands of the western Indian Ocean, and discusses potential prospects and problems associated with its development. The coastlines of eastern Africa and the islands are characterized by warm and relatively unpolluted waters with a wide variety of biotopes and high biodiversity, well suited for several types of aquaculture development. Such development presents prospects for increasing food security for coastal communities and new sources of income; both for the local economy and for export markets. However, unregulated growth of certain types of coastal aquaculture could result in serious environmental problems and social conflicts in eastern Africa (7-9).

\section{COASTAL AQUACULTURE IN EASTERN AFRICA}

The oldest forms of coastal aquaculture in eastern Africa date back some 200 years to the barachois ponds in Mauritius (10). These coastal ponds are constructed with rocky walls that provide semi-enclosures for the rearing of fishes, oysters and crustaceans. The rocky walls have gaps, but their functional simplicity assures a net influx of organisms that can be harvested. Some

24 barachois were operative in 1995 and production levels of fish reached $35 \mathrm{t}$, but these have recently fallen due to problems of poaching and from unwanted predatory fish species (11). Other forms of coastal aquaculture in eastern Africa have only begun to develop in the past three decades. These include farming of red seaweeds, penaeid shrimps, mangrove crabs, brine shrimp, abalone, edible bivalves, pearl oysters and fishes.

\section{Seaweed Farming in Eastern Africa}

The culture of red seaweeds in eastern Africa is quite recent, and the development has mainly taken place in Zanzibar, Tanzania 
until now, but it is also spreading to mainland Tanzania and neighboring Mozambique and Kenya. Tanzania's production has been increasing steadily and reached 7000 t in 1999 (Fig. 1).

Keto Mshigeni and Adelaida Semesi of the University of Dar es Salaam introduced the idea of farming seaweeds into Tanzania during the 1970s $(12,13)$. Adelaida Semesi pioneered the introduction of farnling techniques especially among women in villages in eastern Zanzibar Island (Unguja).

Two species of seaweeds have been farmed since 1989: Eucheuma denticulatum (formerly E. spinosum) and Kappaphycus alvarezii (formerly E. cottonii). These species are found naturally in East Africa (14), and used to be collected from the wild for export to France and Denmark. Although these species are found locally, the farmed strains are mainly imported from the Philippines, and the consequences of this introduction should be studied further.

The method of farming is the tie-tie system whereby fronds of seaweeds are tied to strings stretched between wooden pegs. These are situated in shallow intertidal lagoons inside the fringing reefs. They grow rapidly (up to $12 \%$ per day) and are harvested at spring low tides each fortnight. The seaweeds are then dried by the villagers, sold to agents and exported to USA and Europe for the extraction of carrageenan polysaccharides as gelling, thickening and emulsifying agents in foods, cosmetics, and phannaceuticals. Commercial interests from the Philippines and Denmark played an important role in developing production and markets, and recently a large corporation from USA has engaged itself in purchasing farmed seaweeds from Tanzania. Growth and survival of these seaweeds have generally been good in eastern Africa, but recent problems of slow growth and disease susceptibility have been experienced with Kappaphycus alvarezii (Matern Mtolera, pel's. comm.). This may be a monoculture-related syndrome.

Socially and economically the fanning of seaweeds initially represented an opportunity for coastal villagers, especially women to earn money $(15,16)$, and as a consequence standards of living in the villages were improved during the first decade of production. Seaweed farming also represents an earning of foreign exchange for the countries of eastern Africa.

The total global market value of carrageenan products annually made by a few multinational corporations is about USD 10 billion and is growing at $3-5 \% \mathrm{yr}^{-1}(17,18)$. Low-grade carrageenan can be ordered over the internet for USD $50 \mathrm{~kg}^{-1}$ (19) or USD $30 \mathrm{~kg}^{-1}$ from the Philippines (20), and high-value prod

Figure 1. Aquaculture production of seaweeds (tonnes dry weight) in Tanzania (1989-2000) based on FAD data (2).

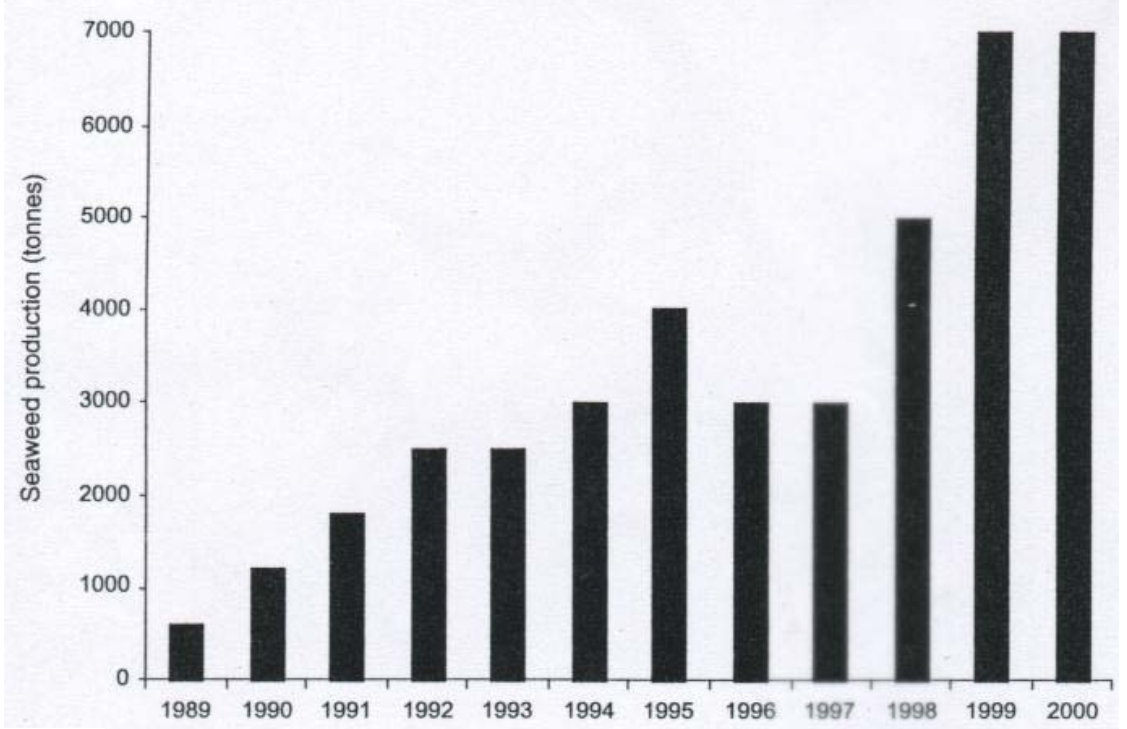

ucts such as "nutraceutical additives" fetch much higher prices. FMC-Biolpolymer is a major corporation based in the USA with expanding interests in eastern Africa, but despite increasing demand and prices on the world market, they have lowered the prices paid to seaweed farmers in Tanzania down to USD 0.09 per $\mathrm{kg}$. The exploitative attitude of the multinational corporations is starkly shown in a quotation from FMC-Biolpolymer (21):

"As a potential seaweed supplier trying to find the best village to work in, you should be delighted to find a village populated by consumers with no or little livelihood options. In this case we call cottonii and spinosum farming the livelihood of last resort. Today we find the most productive and consistent farmers from villages like these... In these places it is too arid to farm or the soil is unsuitable and the reefs have been destroyed and fish stocks decimated. .. Your ultimate goal is to make seaweed farming become a way of life for the villagers. This happens after five or so years. At this stage people don't think too much about price, they just farm because they have always fanned. Their children will follow them into that career."

It is clear that seaweed farming has further potential in eastern Africa, but the monopoly control of prices unfortunately ensures super-profits for multinational corporations and yet abject poverty for coastal villagers.

\section{Experiences with Shrimp Farming in Eastern Africa}

The shrimp (also referred to as "prawn") species that have been cultured in eastern Africa include Penaeus monodon, $P$. indicus, $P$. semisulcatus and Metapenaeus monoceros, but the main emphasis is upon the first species due to its high growth rate and market value.

The first attempt to farm penaeid shrimps in eastern Africa was at Malindi, Kenya, by an F AO-supported project. Production commenced in 1989 and rose to $227 \mathrm{t}$ in 1990, but steadily decreased thereafter and then collapsed in 1995 (Fig. 2). Kenya has since produced about I to $2 \mathrm{t}$ of farmed shrimp per year. A 60 ha shrimp farm exists at Ngomeni in a cleared mangrove area. There is currently a legal conflict surrounding a new and controversial shrimp farm project proposal for the Tana river delta.

In the Seychelles, there is one project on the small remote sandy island of the Coetivy owned by the parastatal Seychelles Marketing Board Trading. They commenced production in 1989 based upon imported Penaeus monodon fry at high stocking densities (up to 60 individuals $\mathrm{m}$-2) in 39 ha of plastic-lined ponds and intensive feeding (22), output peaked at 649 $\mathrm{t}$ in 1998, but production has since fallen (Fig. 2). The project recently lost a case in the Supreme Court over labor disputes, but apparently refused to comply to pay salaries owed to its employees.

In Tanzania, a project was initiated in 1986 by a Norwegian company in cooperation with the Bagamoyo Development Cooperative. The project never materialized as it was thwarted by corruption in land allocations. Recently, other small commercial initiatives have commenced production in the I3agamoyo area.

A major controversy emerged in Tanzania during 1996-1998 with the exposure of a proposal for a giant-sized shrimp farm project to be situateu in the Rufiji mangrove lurest conservation area. A worst-case scenario appeared to be looming (7) in which a notorious weapons dealer (23) was attempting to gain control over 19000 ha of land in Rufiji. The project was opposed by the majority of villagers of Rufiji, who were supported by forestry managers, Tanzanian and foreign researchers (24), 
national environmental authorities (NEMC), environmental journalists, and lawyers. Finally, legal action by villagers with the support of the Lawyers' Environmental Action Team and Issa Shivji gained a legal injunction to halt the project.

In Mombasa during 1998, in the wake of the Rufiji controversy, environmental NGOs from Kenya and Tanzania held a workshop on mangrove conservation and industrial shrimp aquaculture. They advocated for management measures by the governments of the region to guard against shrimp farm projects that lack local support and result in large-scale mangrove conversion (9).

Madagascar has become the major producer of cultured shrimp in the region with 2 large projects at Mahajanga and Morondova with French technology and capital involved (25). The production reached 3486 tons in 1999 (Fig. 2), and further expansion is underway. The International Finance Corporation (World Bank affiliate) was involved in Mahajanga and is now funding the construction of a new 1000 ha project there (26).

In Mozambique, a small shrimp farm was attempted at Costa da Sol, just north of Maputo, in the early 1990s, but failed to produce. A South African investment in a shrimp farm in a mangrove area near Quissanga in northern Cabo Delgado province was reported by fisherfolk, but unknown to environmental authorities in 1997. Large-scale shrimp farming that may cause environmental impacts (27) is currently under planning in Mozambique with 7500 ha allocated in the Maputo area, 19500 near Beira and 6000 ha near Quelimane. Chinese interests have also been negotiating with Mozambican authorities for a major project proposed for north of Beira.

In South Africa, the farming of shrimps (mainly Penaeus indicus) has taken place at aMatikulu and Mtunzini in KwaZuluNatal province since 1992. Production reached $104 \mathrm{t}$ in 1998 (28). The F AO data (2) suggest that $P$. indicus and $P$. monodon production in South Africa occurs on the Atlantic coast, but we assume that it should be the Indian Ocean coast.

\section{Aquaculture of Other Organisms in Eastern Africa}

Edible oyster (Saccostrea cucullata) culture has been tried in mangrove areas in Gazi Bay, Kenya (29) and may have a potential along the east African coast (30). Cockles also present possibilities (31), as do several other edible bivalves. Mussels have been cultured in South Africa, but these are based on an imported invasive species, Mytilus galloprovincialis, from the Mediterranean and annual production has been erratic and faced

Figure 2. Aquaculture production of penaeld shrimp (tonnes) in eastern Africa (1989-2000) based on (2).

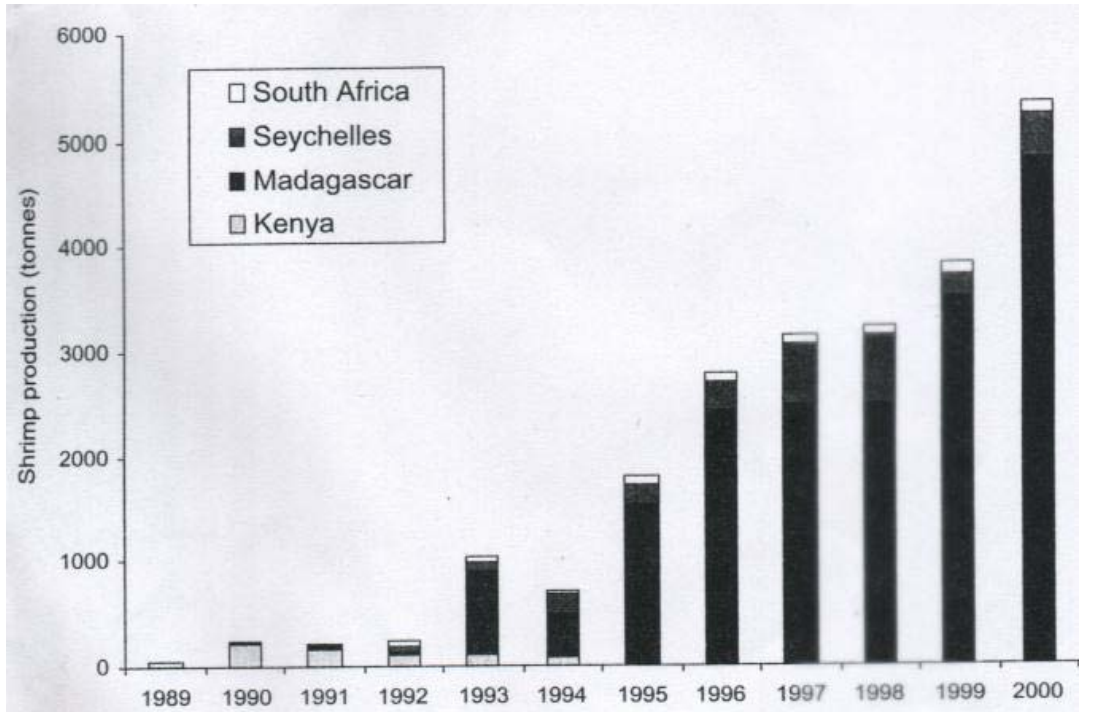

problems with toxic algae. An imported oyster, Crassostrea gigas, was cultured until 1997 but has been abandoned due to problems with toxic algae and mud blister worms (28).

At Praslin Island, Seychelles, a small farm successfully grows black-lipped pearl oysters (Pinctada margaritifera) that produce highly valuable black pearls and giant clams (Tridacna spp.). During the mass death of corals and giant clams in the extreme warm conditions of the central Indian Ocean during the EI Nino event in March 1998, the only giant clams to survive in Seychelles were those in the aquarium tanks of this small farm. The subsequent voluntary re-stocking of Tridacna clams back to the reef from the farm is an interesting positive contribution by aquaculture to the environment (Kari Nilsen, pers. comm.).

Integrated farming systems where several species are co-cultivated in order to improve resource-use efficiency, and reduce waste outputs and environmental impacts are of special interest. Experiments are presently underway with integrated multispecies pond systems at the Institute of Marine Sciences in Zanzibar, where milkfish, rabbit fish, and mullets are cultivated together with mollusks and seaweeds (32). Integrated farming of seaweeds and abalone are already applied on a commercial scale in South Africa. Here the seaweeds are grown in the nutrient rich outlet water from the abalone tanks, and then used as feed for the abalone. This system is very cost-efficient and has reduced needs to harvest wild seaweeds by $40 \%$ (C. Halling, pers. comm.).

Fish species that are herbivorous (e.g. Siganus or Scanls) or detritus-feeding (e.g. Chanos or MugU) provide further potential for coastal aquaculture, since they are ecologically more energyefficient and less polluting than carnivorous species (e.g. Epinephelus or Lutjanus). The latter may, however, fetch a higher market price, especially if one ignores externalized ecological costs. Mangrove crabs (Scylla serrata), brine shrimp (Artemia), and sea cucumbers (Holuthuria) are other candidates for increased aquaculture production.

\section{ENVIRONMENTAL CONCERNS OF COASTAL AQUACULTURE}

Environmental impacts of coastal aquaculture arise from the consumption of resources, such as land, water, fry and feed, their transformation into products valued by society, and the subsequent release into the environment of wastes $(6,33,34)$. Negative effects may be direct, through release of eutrophicating sub stances, toxic chemicals, the transfer of diseases and parasites to wild stock, and the introduction of exotic and genetic material into the environment, or indirect through loss of habitat and niche space, and changes in food webs. Perhaps the most critical environmental aspect to address for individual aquaculture systems is that of net loss or gain of animal protein, which has direct socioeconomic implications.

Coastal communities may suffer socioeconomic problems in the backwaters of polluted and deteriorated natural environments $(5,6,35)$. Aquaculture activities often utilize common property resources such as land, water and mangrove areas. These common property resources contribute greatly to social equity, since net monetary benefits are distributed to large groups of politically and economically marginal people. The development of shrimp pond aquaculture has, for example, caused privatization and deterioration of common property resources, and consequently this economic activity has brought about social displacement and marginalization of fishermen and agriculturists $(5,6)$. 
The development of coastal aquaculture in eastern Africa can learn from many positive and negative lessons experienced in other parts of the world. Aquaculture is basically an ecological process, and many environmental concerns can be ameliorated if culture practices are more in tune with ecosystem processes. Unregulated expansion of aquaculture may, for example, cause deteriorating water quality in the production site as well as the recipient, which in turn lead to physiological stress for the cultured organisms. This results in lowered immune response, which increases the risk for disease outbreaks. The wide-scale abandonment of shrimp ponds in many countries has, for instance, often been due to the proliferation of initially successful farms that ultimately overwhelms the system and triggers disease outbreaks (36). In this context, it is important to regulate the local and regional development of coastal aquaculture to avoid exceedance of the "waste" absorbing or assimilate capacity of the environment. By doing so, the risk of deteriorating water quality and subsequent disease problems is lowered, and consequently the need for chemical and antibiotic use is reduced. Conflicts with other resource users are also minimized.

\section{FOOD SECURITY: DOES AQUACULTURE ALWAYS GENERATE A NET GAIN OF FISH AND SHELLFISH?}

Many people believe continued growth in aquaculture will automatically relieve pressure on deteriorating wild fish stocks, allowing their populations to recover while supplying an ever-increasing demand for protein to nourish a growing human population. However, current trends in the world aquaculture industry do not always support that belief. As practiced today, aquaculture is a mixed blessing for the sustainability of ocean fisheries. The diversity of production systems leads to an underlying paradox: aquaculture is a possible solution, but may also be a contributing factor, to the collapse of fisheries stocks worldwide. The full acknowledgement of this paradox is vital for the successful development of aquaculture in eastern Africa.

\section{Feed Inputs}

The farming of carnivorous species such as grouper, sea bass, shrimp, etc. requires vast quantities of wild-caught fish as feed indeed, 2 to $5 \mathrm{~kg}$ of wild fish biomass to produce a single $\mathrm{kg}$ of these highly commercial species (37). In contrast, the farming of herbivorous and omnivorous species such as rabbit fish, milkfish, and tilapia that eat aquatic plants and algae, or oysters, clams, and mussels that filter plankton from the water can make a large contribution to local, regional, and global fish supplies as well as food security. However, the trend toward industrial-scale production also of herbivores and omnivores has led to increasing use of manufactured feed pellets that incorporate fish meal and fish oil, also for many of these species (37).

At the same time as we are farming up the food chain, we are fishing down the food web (38), partly as a result of increased demands for fishmeal. Despite the surge in production of farmed fish, the tonnage of wild fish harvested has not declined. As wild catches of large, valuable carnivorous fish such as cod and tuna have decreased, there has been a gradual shift to harvesting of smaller, less valuable species such as anchovy that are ground into fish meal or fish oil for use in manufacturing feed for livestock and farmed fish. Currently, about II3 of the total harvest of capture fisheries is used to produce fish meal, one third of which is used by the aquaculture industry (37). Between 1986 and 1997,4 of the top 5 , and 8 of the top 20 wild species harvested from the Ocean were small fishes used in production of animal feed (39). The heavy fishing pressure on small oceanic fish for fish meal has also led to the depletion of food for wild carnivorous fish such as tuna, as well as seals, dolphins, and sea birds.

The wasteful resource use in feed management can be amel iorated by improved feeds that are based on formulations that use greater amounts of vegetable protein and less fish meal and fish oil (37).

\section{The Mangrove Conversion Paradox}

More than $50 \%$ of the world's mangroves have been removed, and the establishment of brackish water ponds has been a major cause behind this loss in many countries $(5,6)$. In recent decades, shrimp farming has been responsible for a significant share of the mangrove conversion. For example, mangrove conversion into shrimp ponds covered 102000 ha in Vietnam in 1983-1987, 65000 ha in Thailand in 1961-1993, and most of the 180000 ha of ponds in Ecuador (reviewed in 5). Local and foreign shrimp farm investors have major interests to expand in eastern Africa, which may have dire consequences for the mangroves in the region.

As a paradox, the productivity and sustainability of fish and shrimp aquaculture is often directly dependent on the continuous support of mangrove goods such as fry and broodstock as well as services including water quality maintenance and erosion control $(33,34,40)$. The industry thus challenges its own life-support system. It has been estimated that the spatial mangrove ecosystem support, or "ecological footprint", required to produce food inputs, nursery areas and clean water, as well as to process wastes, was up to 160 times the surface area of a semi intensive shrimp farm (41, 42).

Making the proper choice of sites for the ponds is one of the easiest and best ways for farmers to limit environmental damage and to improve the lifetime of their ponds $(6,36)$. There is no defense for large-scale clearance of mangroves to accommodate aquaculture ponds. First, mangrove soils are not suitable for aquaculture purposes. Secondly, the opportunity cost of converting mangroves is very high in terms of the substantial natural production of fish and shellfish supported by this system. Thirdly, the adverse impacts on the livelihood of coastal communities dependent on mangrove goods and services are considerable $(6,43)$.

Each ha mangrove can generate 1100-11 $800 \mathrm{~kg}$ fisheries catch mean $(3600 \mathrm{~kg})$ (reviewed in 40$)$, which illustrates the potential lifesupport value of mangroves. This productivity is, for example, much higher than the $10-370 \mathrm{~kg} \mathrm{ha}^{-1} \mathrm{yr}^{-1}$ proposed for coral reefs (44). In developing countries, the annual market value of fisheries supported by mangroves range from USD 900 to USD $12400 \mathrm{ha}^{-1}$ mangrove (USD $.3400 \mathrm{ha}^{-1}$ as mean) (40). It must be emphasized that this value is based on one mangrove good, i.e. fisheries production, alone. Additional efforts to estimate the economic value of forest resources and ecological services generated by mangroves would further highlight the significant value of this ecosystem and its importance to subsistence, local and national economies. The significant economic value of mangroves places serious doubt on the low land purchase price or annual lease fees (sometimes only a few dollars per ha mangrove) paid by aquaculture prospectors. Such conversions definitely imply the privatization of a common property resource.

\section{Bycatch Problems Associated with Fry Inputs}

The farming of fish, shrimps and crabs depends on fry (larvae) collected from the wild or reared in hatcheries from eggs of wild broodstock, thereby putting additional pressure on marine fisheries. The quantity of by catch associated with such wild catches is directly proportional to the natural abundance of the target species for culture. Fish and shrimp fry are caught in coastal waters using fine-meshed nets that inevitably trap large quantities of fish and crustaceans, which are usually sorted out and discarded on land. For example, milkfish (Chanos chanos) constitute only $15 \%$ of total fish fry in daily inshore collections by seine net (45). The annual utilization of 1.7 billion wild fry for stocking in Philippine milkfish ponds (46) means a correspond- 
ing loss of nearly 10 billion fry of other fish species alone. In India and Bangladesh where ponds are predominantly stocked with wild Penaells monodon shrimp fry, up to 1000 fish and other shrimp fry are discarded for every penaeid shrimp collected (5). The amount of shrimp fry bycatch destroyed globally is staggering and could have major consequences for biodiversity and capture fisheries production.

Closure of the hatchery cycle by improved breeding and domestication programs would reduce the demand for wildcaught fish and crustacean fry as well as

broodstock, and consequently the bycatch problems associated with these fisheries are ameliorated (6). Another positive side effect is that worldwide transfer of fry and broodstock of cultured organisms would be halted, thus minimizing the risk of introducing alien species and spreading disease.

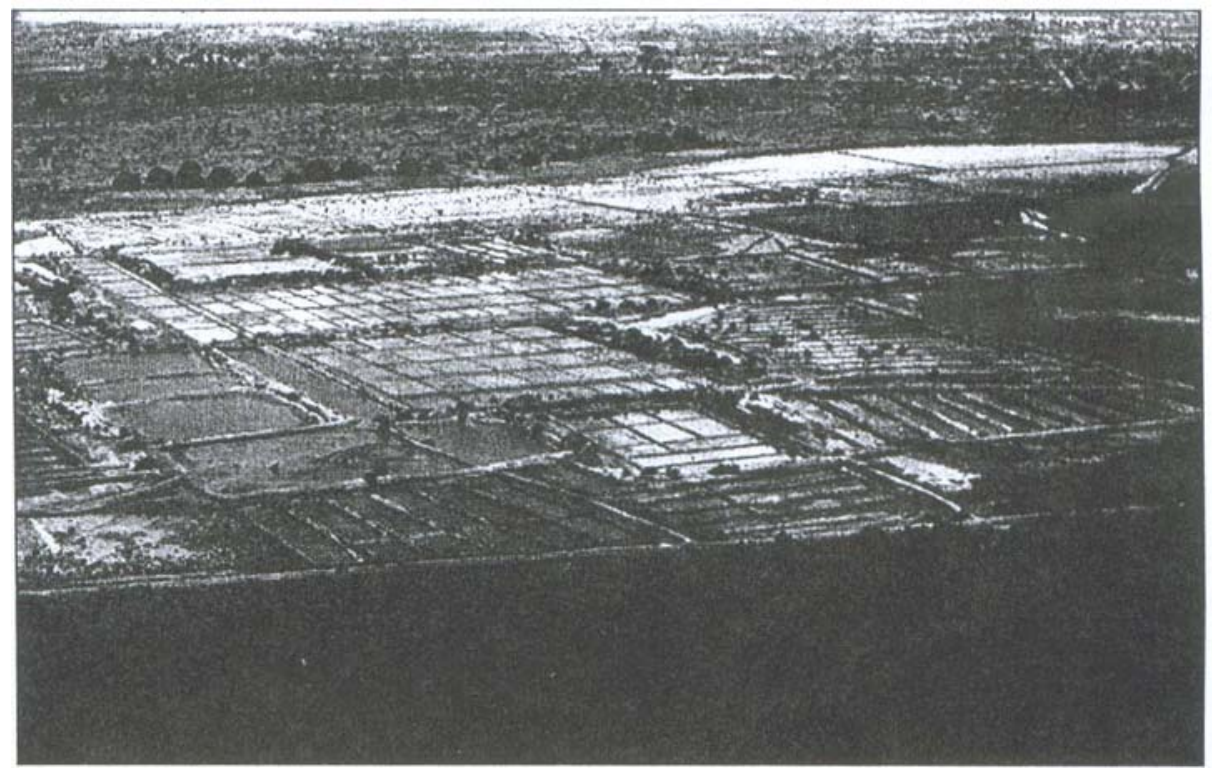

Tanzania mangrove clearance for salt production, which may be a precursor to shrimp ponds. Photo: I. Bryceson.

\section{DISCUSSION}

Aquaculture is a very diverse activity with a large number of species and technologies used, each with their environmental, .social and economic impacts. There is a clear difference between large scale intensive and industrial aquaculture that generates export incomes, but also tends to produce more environmental problems, and small-scale integrated aquaculture that satisfies the protein needs of rural communities, and is more environmentally friendly. Both are needed in Africa, but have their restrictions and advantages, and must be developed within the capacity of ecosystems to maintain biodiversity, and sustain social and economic development.

The pressure for development of aquaculture of cash crops, such as seaweeds, shrimp and abalone has mainly been by private investors, while attempts to improve local food security has largely been pursued by aid and development agencies. However, success, especially for small-scale aquaculture, has so far been rather limited in eastern Africa. One restriction to coastal

aquaculture development in Africa has probably been the lack of traditional knowledge in this field. Compared to Asia, where aquaculture has traditions of more than 2000 years, fishing and intertidal gathering have until recently been the main ways of obtaining food along the east coast of Africa.

The future balance between farmed and wild-caught fish, the total supply of fish available for human consumption, and the very health of the marine environment will depend to a large degree on future trends in aquaculture practices. One of the most unfortunate development scenarios of aquaculture in eastern Africa would be if all efforts were put on a rapid expansion and intensification of shrimps and high-value carnivorous fish, where production of I kg uses 2 to $5 \mathrm{~kg}$ of wild-caught fish processed into feed pellets. This type of aquaculture definitely does not contribute to increased fish supply, especially in a region where poor people usually eat small fresh or dried pelagic fish. Apart from the risks of overfishing and collapse of local stocks, there is a risk that capital intensive aquaculture will pay more for these small fish than the local people can afford, then use it as feed for export commodities, thus depriving local people of affordable fish.

Bycatch problems associated with fry and broodstock fisheries, and large-scale deforestation of mangroves to accommodate aquaculture ponds are other serious concerns that result in net loss to seafood production in the region. As a paradox, the conversion of mangroves also challenges the aquaculture industry's own lifesupport system. There is no excuse for major coastal aquaculture development at the expense of viable mangrove ecosystems, which threatens the livelihood of coastal communities.

Contrary to common belief, most aquaculture systems developed in the last few decades, are not an independent food producing process, but are strongly coupled to Nature' s subsidies and services to sustain production. Important ecological principles should be borne in mind when planning for sustainable development of coastal aquaculture in Africa. The "ecological foot print" can help to indicate the development limitations of aquaculture systems $(47,48)$. Without clear recognition of its dependence on natural ecosystems, the aquaculture industry is unlikely to develop to its full potential or continue to supplement ocean fisheries. In line with Naylor et al. (37) we recommend the adoption of 4 priority goals for aquaculture in Africa:

- Encourage farming of species lower on the food web-that is, fish with herbivorous diets, filter feeders such as oysters or plants such as seaweeds

- Improve feed efficiency in industrial aquaculture systems and develop substitutes for fish-derived feed ingredients

- Develop integrated fish farming systems that use multiple species to reduce costs and wastes while increasing productivity

- Promote environmentally sound aquaculture practices and resource management.

Much could be learnt from successes and failures in Asia. Shrimp farming in Asia has been far from as successful as the industry claims, especially when environmental costs are internalized. Despite heavy use of chemicals and antibiotics $(49,50)$, the disease problems prevail and an increasing number of ponds and entire farming areas have had to be permanently abandoned (36). There is also an increasing awareness among consumer organizations in countries importing shrimp, and recently several shipments from Asia have been stopped because of antibiotic residues. In fact, some farmers are realizing these problems and now reduce the farming intensity and overcrowding of shrimp grow-out ponds by setting aside ponds for treatment of waste water, creating buffer zones between ponds, and integrating systems for improved resource-use efficiency. Interesting experiments with multi-species integrated systems (as those begun in Zanzibar) may be further developed to combine silviculture of mangroves with fishes (especially herbivorous and detritus-feeding species), shrimps, crabs, clams, etc. as are being tried in several countries in South East Asia. It is also important to appreciate and learn from traditional knowledge based in coastal aquaculture technology in Asia such as the Indian "pokali" and 
Indonesian "tambak" system (5). The future development of coastal aquaculture in eastern Africa must, however, be based on native species, and the local environmental conditions as well as socioeconomic and institutional setting.

Principles of social equity and transparent democratic procedures are imperative if aquaculture is to be developed sustainably. Short-term profits for a small number of opportunistic investors should not be allowed to infringe upon the resource access rights or to harm the long-term interests of coastal communities. In cases where awareness of environmental consequences is low, or where the impacts do not affect profitability of the farmers and retailers, there is little incentive for the industry to regulate itself. In this context, policymakers must take responsibility by incorporating proper incentive structures, de

\section{References and notes}

1. National Research Council 1999. Sustaining Marine Fisheries. National Academy Press, Washington Dc. 2. FAO 2001. Fishstat Plus version 2.30. (http://www.fao.org)

3. Pedini, M. 2000. Bridging the gap. FAO Aquaculture Newsletter FAN 24,4-9 (also presented at WAS Sydney 1999).

4. Naylor, R., Goldberg, R., Mooney, H., Beveridge, M., Clay, J., Folke, c., Kautsky, N., Lubeheneo, J., Primavera, J. and

Williams, M. 1998. Nature's subsidies to shrimp and salmon farming. Science 282, 883-884.

5. Primavera, J.H. 1998. Tropical shrimp farming and its sustainability. In: Tropical Mariculture. de Silva, S. (ed.). Academic Press, pp. 257-289.

6. Ronnback, P. 2001. Shrimp Aquaculture-State of the Art. Swedish International Development Agency (Sida), Stockholm \& Swedish EIA Centre, Swedish University of $\quad$ Agricultural Sciences (SLU), Uppsala. Report I, 58 pp.

7. Bryccson, I. 1997. Shrimp farm threatens Tanzanian coast and people. Development 7 today 7, IL

8. Bryceson, I. 200 I. Coastal aquaculture developments in Tanzania: sustainable and non sustainable experiences. Keynote paper presented at 2"' WIOMSA Scientific Symposium .22 $2^{\text {nd }}-26^{\text {th }}$ October, 2001 in Dar es Salaam, Tanzania.

9. Earth Summit Watch 1998. (http://carthsummitwalch.org/shrimp/national report/crtanzan.html)

10. ITC (international Trade Centre) 1999. Supply Survey on Mauritius' Fish and Fish Products.

(http://www.intraccn.org/iatp/survcys/fishifishmau.html)

II. IELS (Institute For Environmental and Legal Studies) 2001. Mauritius and its Environment.

(http://www.intnet.mu/ieis/index.hlm)

12. Mshigeni, K.E. 1976. Seaweed farming: a possibility in Tanzania's coastal ujamma villages. Tanzania Notes Records 79-80, 99-105.

13. Scmcsi, A.K. and Mshigeni, K.E. 1977. Studies on the carrageenans from economic red algal genns Eucheuma in Tanzania. Bot. Mar. 20, 239-242.

14. Jaasund. 1976. Intertidal Seaweeds in Tanzania: A Field Guide. University of Tromso, Norway, $160 \mathrm{pp}$.

15. Msuya, F. 1993. Seaweed fanning in Zanzibar: an amazing story. ALCOM News 11 11-15.

16. Msuya, F. 1995. Socio-economic and environmental impact of seaweed fanning in the east coast of Unguja, Tanzania. In: Proc. National Workshop on Integrated Coastal Zone Management in Tanzania. Zanzibar, $9^{\text {th }}-12^{\text {th }}$ May, 1995, $24 \mathrm{pp}$.

17. Borgeson, N., Brunncr, 13. and Sakata, K. 1999. Food Additives. (http:// scup.sric.sri.com/Public/Reports/FOODA000/Navigation.html)

18. Taylor, D. 2000. Mindanao Seaweed Growers, Traders Organize to Prop Uplnduslry. (http://www.mindanao.org/news10009/18.hlm)

19. Alexander Essentials Ltd. 2001. Carrageenan Sales. (http://www.alexander-essentials.com/

20. PhilimportExport Inc. 2001. Carrageenan Products. (http://www.philimportexpoI1.com)

21. Ask, E. 2000. Suggestions for coltonii and spinosum suppliers. FMC Biopolymer Publ. Philadelphia, USA, $21 \mathrm{pp}$

22. Dc Muylder E., Gunasekera, U.P.D. and Valabhj, M. 1996. Shrimp fanning on Coetivy, an isolated coral island in Seychelles. Paper presented at Second International Confer ence on the Culture of Penaeid Prawns \& Shrimps, May 1996, Iloilo City, Philippines.

23. Lissu, T.A.M. 1998. The Mod Rush for "Pink Gold": A Socio-legal Study' of the Rufiji Delta Prawn Farming Project in Tanzania. African Centre for Technology Studies (ACTS), Nairobi, Kenya, 91 pp.

24. Fottland, H. and Sorensen, C. 1996. Issues Related to the Establishment of Prawn Farms in Tanzania with an Example from the Rufiji Delta. Catchment Forestry Report, 1996: 4

25. Kannokolias, I. 2000. Mahajanga Project. (http://www.ifc.org/publications/pubs/rog/ $\operatorname{rogl} /$ chap4.pdf)

26. IFC (International Finance Corporation) 2001. (http://www.ifc.org/ar200Ildownloads/ projectApprovals.pdf)

27. Fcrnandes, A. and Hauengue, M.D.A. 2000. Strategic Action Plan for Land-Based Sources and Activities Affecting the Marine, Coastal and Associated Fresh Water Environment in the Eastern African Region. (http://www.unep.org/eaflDocs /SAPEaf5/ mozambiq.htm)

28. Probyn, T. 1999. An Overview of Mariculture in South Africa. (http:// www.environment.gov.za/mcm/econom/maricult!overview.htm)

29. UNEP 1998. East African Atlas of Coastal Resources: Kenya. United Nations Environment

Programme, Nairobi, $119 \mathrm{pp}$.

30. Mgaya, Y.D. 2001. Experimental spat collecting of the edible oyster, Saccostrea cucullata Born in the Kunduchi Creek, Dar es Salaam. Tanz. J. Sci. 27,67-81.

31. Kayombo, N.A. 1991. A system for experimental fanning of the edible bivalve Anadara antiquata (Linnaeus, 1758) in Tanzania. In: Aquaculture in Africa. Koop, K. (ed.). Harare, Zimbabwe, pp. 57-71.

32. Mmochi, A., Mozes, N, Kite-Powell, H.L., Dubi, A.M., Gordin, H., Jiddawi, N., Kissil, G.. Msuya, F. and Mwangamilo, J. 2001 Design and preliminary results of an integrated mariculture pond system at Makoba, Zanzibar, Tanzania. Paper presented at $20^{\prime \prime \prime}$ Anniversary Conference of the Institute of Marine Sciences, University of Dar es Salaam. Zanzibar, 28'h June-1 ${ }^{\text {st }}$ July, 1999, 19 pp.

33. Beveridge, H.C.M., Phillips, M.J. and Macintosh, D.J. 1997. Aquaculture and the environment: the supply of and demand for environmental goods and services by Asian aquaculture and the implications for sustainability. Aquacult. Res. 28, 797-808

34. Kautsky, N.. Folke, c., Ronnb5ck, P., Trocll. M., Beveridgc, M. and Primavera, J. 2001. Aquaculture. In: Encyclopedia of Biodiversity, Volume I. Levin et a1. (eds). Academic Press, pp. 185-197. velopments of Integrated Coastal Zone Management (ICZM), Environmental (and social) Impact Assessment (EIA) and other organizational and institutional frameworks including trade rules and regulations. Governments have a key role to play in developing regulations to protect coastal ecosystems and in re-examining subsidies to unsustainable marine fisheries, Development agencies are strategically placed to help in developing and implementing sustainable production practices and in financing otherwise economically and socially unattainable reforms in developing countries. If public and private interests act jointly to reduce the environmental costs generated by aquaculture, present unsustainable trends can be reversed and aquaculture can make an increasingly positive contribution to global fish supplies.

35. Barraclough, S. and Finger-Stich, A. 1996. Some ecological and social implications commercial shrimp farming in Asia. United Nations Research Institute for Social development \& World Wildlife Fund, Discussion Paper.

36. Kautsky, N., Ronnback, P., Tedengren, M. and Troetl, M. 2000. Ecosystem perspectives on the management of disease in shrimp pond fanning. Aquaculture 191, 161

37. Naylor, R.L., Goldburg, R.J., Primavera, 1.H., Kautsky, N., Beveridge, M.C.M., Clay, J., Folke, c., Lubeheneo, J., Mooney, H. and Troell, M. 2000. Effect of aquaculture on world fish supplies. Nature 405,1017-1024.

38. Pauly, D., Tyedmers, P., Froese, R. and Liu, L.Y. 2001. Down with fisheries and up with aquaculture. Papcr presented at $A A A S$ (American Association for the Advancement of Science) Meeting, San Fransisco 2001.

39. F AO 1999. The State at the World Fisheries and Aquaculture 1998. Food and Agriculture

Organisation, Rome.

40. Ronnback, P. 1999. The ecological basis for the economic value of mangrove forests in seafood production. Ecol. Eco/1. 29,235-252.

41. Larsson,. I.. Folkc, C and Kautsky, N. 1994. Ecological limitations and appropriations

of ecosystem support by shrimp limning in Colombia. Environ. Mgmt 18, 663-676

42. Kaut-sky, N., Berg, II., Folke, c., Larsson,.I. and Troell. M. 1997. Ecological footprint as a means for the assessment of resource use and development limitations in shrimp and aquaculture. Aquacult. Res. 28, 753-766.

43. Semesi, A.K. 1998. Mangrove management and utilisation in eastern Africa. Ambio 27,620-626.

44. Alcala, A.C. 1988. Effects of marine reserves on coral fish abundance and yields of Philippine coral reefs. Ambio $17,194-199$.

45. Bagarinao, T. and Taki, Y. 1986. The larval and juvenile fish community in Pandan Bay, Panay Island, Philippines. In: Indo-Pacific Fish Biology Uyeno, T. Arai, R., Taniuchi, T. and Matsuura, K. (cds). Ichtyological Society or Japan, Tokyo. pp. 739.

46. Bagarinao, T. 1998. Historical and current trends in milkfish farming in the Philipines. In:

Tropical Mariculture. de Silva, S. (cd.). Acadcmic Press, pp. 381-422.

47. Folkc, C, Kautsky, N., Berg, 11., .Jansson, A., Larsson, .I. and Troell, M. 1998: The ecological footprint concept for sustainable seafood production-a review. Ecol. Applic. 8,63-71.

48. Ronnback, P., Troell, M., Zetterstrom, T. and Babu, D.E. 2002. Shrimp Hatcheries in Andhra Pradesh, India: Why is the industry dependent on mangrove preservation. Environ. Cons. (Submitted)

49. Graslund, S. and Bengtsson, B-E. 2001. Chemicals and biological products used in South-East Asian shrimp farming, and their potential impact on the environment - a review. Sci. the Total Environ. 280, 93-131.

50. Holmstrom K., Graslund, S., Wahlstrt;m. A., Poungshompoo, S., Bengtsson, B.-E, and Kaulsky, N. 2002. Antibiotic use in shrimp farming and implications for envirornmenttal impacts and human health. Int. J. Food Sci. Technol. (in print).

Patrik Ronnback has a PhD in systems ecology, and his research interests relate to ecological economics analysis of fisheries, aquaculture and mangrove ecosystem. His address: Department of Systems Ecology, Stockholm University, SE10691 Stockholm, Sweden.

E-mail: pat@system.ecology.su.se

Ian Bryceson is a coastal and marine ecologist from Tanzania with experience in aquaculture development. He currently working as research professor. His address: Centre for International Environment and Development Studies, Noragric, Agricultural University of Norway, N-1432 As, Norway.

E-mail: ian.bryceson@noragric.nlh.no

Nils Kautsky is professor of marine ecotoxlcology at Stockholm University, and Deputy Director of the Beijer International Institute for Ecological Economics at the Ro Swedish Academy of Sciences. He has more than 20 year_of experience of coordinating projects on marine systems ecology and coastal area management in Africa, Asia and Latin America. His address: Department of Systems Ecology, Stockholm University, SE-106 91 Stockholm, Sweden. E-mail: nils@system.ecology,su.se 